\title{
A Note on the Quantitative Analysis of Hadith
}

\author{
Hiroyuki Yanagihashi \\ University of Tokyo
}

\begin{abstract}
Hiroyuki Yanagihashi observes how recent developments make the quantitative analysis of hadiths a "promising" endeavor. The question then becomes: why and how the text of certain hadiths, taken literally, appear to contradict established Sunnī legal doctrine? The logical presumption is that either traditionists transmitted the jurisprudence of ancient legal systems that were eventually replaced by later-derived fiqh rulings or they reformulated the hadìths in the process of transmission to develop the rulings underlying those later legal systems. By way of example, and to investigate these possibilities, Yanagihashi proposes quantitative analysis to trace variations within the texts of two prominent hadiths over the course of more than a century. His analysis yields conclusions that corroborate other work in hadith-related studies from recent years (e.g., those of Behnam Sadeghi on a larger scale in his "Traveling Tradition Test," and Intisar Rabb with respect to a select hadìth in her evaluation of the doubt canon, and others): an increase in textual variation does not necessarily correspond to a change in legal doctrine; the number of variants can increase over time, even after the compilation of Sunnī Islam's six canonical hadìth collections. His methods represent and propose new directions for quantitative analysis at the intersection of hadìth and law in early Islamic history.
\end{abstract}


Towadays, it is easy to deal with a large quantity of data on 1 a personal computer, which makes a quantitative analysis of hadith promising. In fact, it is not rare that an unexpected outcome is obtained from a quantitative analysis. In this essay, I apply this methodology to the question of whether traditionists retained or developed a legal system in parallel with the fiqhsystem represented by that of the four Sunnī schools of law, to show its utility and caveats.

We know that according to Sunnīs the Prophetic Sunna is the second source of Islamic law. However, many researchers of Islamic law must have felt from time to time that this is not always the case. There are many hadiths which, at least taken literally, contradict positive solutions adopted by jurists. (Conversely, in many cases jurists invoke hadiths that are not recorded in hadīth collections, as well.) Suffice it to cite an example. According to a hadīth ( hadīth 1) recorded in alBukhārī's Șah̄inh, 'Amr b. al-Sharīd, a Successor living in Taif, narrated:

Al-Miswar b. Makhrama came and put his hand on my shoulder. I went to see Sa 'd [b. Abī Waqqāṣ] with him. Abū Rāfi said to al-Miswar, "Don't you tell this man to buy from me my house which is in my yard?" Sa 'd said, "I will not pay more than four hundred either in cash or in installments. Abū Rāfi' said, "I was offered five hundred in cash, but I refused. If I had not heard the Prophet saying, 'A neighbor is more entitled to his nearness,' I would not sell it to you."'

No less than fifty-three hadiths referring to the same event are recorded in nineteen works including alBukhārī's Șahīh (two hadīths to the same effect are recorded there) and the Sunans of Abū Dāwūd, Ibn Mājah, and al-Nasầ'̄. According to the opinion unanimously held by Sunnīs, if one of the co-owners of an undivided immovable property sold his share to a third party, the other co-owners can exercise the

$1 \quad$ Abū 'Abd Allāh Muḥammad b. Ismā'îl b. Ibrāhīm b. al-Mughīra alBukhārī, al-Jāmi 'al-musnad al-șaḥihh al-mukhtașar min umūr rasūl Allāh șallā Allāh 'alay-hi wa-sallama wa-sunani-hi wa-ayyāmi-hi, ed. Muhammad Zuhayr b. Nāṣir alNāṣir, Cairo: Dār Ṭawq al-Najāt, 1422 A.H., 9:27, no. 6977. 
right to pre-emption (haqq al-shuf'a) to repurchase the share by paying the buyer the same amount that the latter spent, i.e., the price and any associated expenses. The right is established also in other circumstances according to some jurists, as suggested by this hadīth. The four Sunnī schools of law unanimously assert that the pre-emption right is established only after the object has been sold, and do not require the one who intends to sell an immovable property or his share to offer a sale to the pre-emptors or to inform him of his intention to sell his share. This is to say, their opinion contradicts this hadith. ${ }^{2}$

This is not an isolated case. There are many legal hadīths whose content contradicts the corresponding fiqh rule, as noted. The question then arises why traditionists recorded such hadiths. Many researchers may be inclined to infer that traditionists made it a rule to transmit hadīths to subsequent generations that they deemed to be authentic or at least that they did not deem to be inauthentic, even if those hadīths were actually abandoned or disregarded by jurists. This inference implies that traditionists, or those among them who were versed in jurisprudence, retained and transmitted hadiths inspired by ancient legal systems that were eventually overshadowed by the fiqh of the four Sunni schools of law. However, we can conceive of another scenario, that is, traditionists did not only retain the ancient legal systems, but also developed their own legal systems.

To verify whether traditionists passed on hadīths inspired by an ancient legal system or they developed their own legal system(s) up to a certain period, let us examine the changes over time in the number of variants of two groups of haditths recorded in fourteen works including the six canonical hadith collections and Mālik's Muwatța', i.e., those related to pre-emption and those related to several prohibited transactions such as muza bana, muhāqala, etc. ${ }^{3}$ (Let us call these Groups 1 and 2, respec-

2 Al-Shāfi 'i attempts to harmonize the opinion of the jurists with this hadith. Abū 'Abd Allāh Muhammad b. Idrīs al-Shāfi '̄i, Ikhtilāf al-ḥadìth, ed. Muhammad Aḥmad 'Abd al-'Azīz, Beirut: Dār al-Kutub al- 'Ilmiyya, 1406/1986, 535—536.

3 Muzābana denotes buying something whose measure, weight, and number are unknown for something (of the same kind) whose measure, weight, or number is known, whether it is wheat, dates, or whatever food, or goods of wheat, 
tively). Ninety-one hadīths belonging to Group 1 are divided into seven sub-groups each of which comprises a number of hadiths that seem to have derived from the same original hadi th, judging from their isnāds and matns. In contrast, it is difficult to classify over three hundred hadīths belonging to Group 2, for most of them are composite hadīths, into which two or more hadīths of different origins were incorporated.

The problem is determining the matn that a hadīth had during a particular period of time. One method is to identify it with the one contained in a hadīth whose $i s n \bar{a} d$ ends with a transmitter (i.e., the teacher who passed on this hadith to the author of a text recording that hadith) who died during that period. For example, according to a hadīth ( hadīth 2) recorded in al-Shāfi 'î's Ummwhich has the isnād Sufyān b. 'Uyayna $\longleftarrow$ alZuhrī $\leftarrow$ Sālim b. 'Abd Allāh, Ibn 'Umar narrated, "The Prophet forbade the sale of dates before they became mature." " It is not certain that this narration ascribed to Ibn 'Umar was identical with the original matn of this hadith, but it is almost certain that this was the matn (variant) that Sufyān b. 'Uyayna related to al-Shāfi ' $\overline{1}$, although we cannot exclude the possibility that the latter changed what he heard from his teacher. Thus, the year 198/814, when Sufyān died, is the terminus ante quem of its generation, i.e., the date by which this matn must have been put into circulation. But let it be identified with the date on which this matn (variant) was put into circulation, for the sake of analysis.

This method poses a practical problem, that of defining

date kernels, herbs, safflower, cotton, flax, silk, etc. Mālik b. Anas b. Mālik b. Abī 'Āmir b. 'Amr b. al-Hārith, Kitāb al-Muwațta', recension of Yahyā b. Yahyā al-Laythī, ed. Bashshār 'Awwād Ma rūf (Beirut: Dār al-Gharb al-Islāmī, 1997), 2:150, no. 1831. Muhāqala is variously defined. To mention two major opinions, according to one opinion, it is defined as a share-cropping contract, i.e., "giving land in exchange for a share of what is produced by the land, say a third or a fourth." Abū 'Umar Yūsuf b. 'Abd Allāh b. Muhammad b. 'Abd al-Barr al-Namarī al-Andalusī, al-Tamhīd li-mā fì al-Muwațta' min al-ma 'ānī wa-al-asānīd, eds. Mușțafā b. Aḥmad al-'Alawī and Muḥammad 'Abd al-Kabīr al-Bakrī, 26 vols. (Rabat: al-Shu' ūn al-Islāmiyya, 13871412/1967-1992), 2:318-19. According to another, it is defined as "selling spikes of wheat for threshed wheat." Ibid., 2:313-14.

4 Abū 'Abd Allāh Muḥammad b. Idrīs al-Shāfi '̄ì, al-Umm, ed. Muḥammad Zuhrī al-Najjār, 8 vols. (Beirut: Dār al-Ma rifa, 1393/1973), 3:47. 
a variant. Let us define it as a matn that contains a particular set of constitutive elements that are juristically meaningful. To take the example of the above-cited hadīth 1, the phrases contained in Abū Rāfi "s statement "my house which is in my yard" (as distinct "my house" without further qualification, as in many other similar hadīths) and the statement of the Prophet that "A neighbor is more entitled to his nearness" are such elements, but not the phrase that "al-Miswar b. Makhrama came and put his hand on my shoulder," among others. As a suggestion, eight hadīths including hadīth 1 are recorded in various works that share exactly the same set of elements, that is, this variant comprises eight hadīths.

Figure 1 represents the changes over time in the number of variants of hadiths belonging to Group $1\left(N_{v}(1, Y)\right)$ and that of variants of hadiths belonging to Group $2\left(N_{v}(2, Y)\right)$ for the period from $150 / 767-768$ to $260 / 874-875$. (I start from 150 , for few hadīths have an isnād ending with a transmitter who died before 150 , for the extant earliest sources that record a substantive number of hadīths are the Muwatța' of Mālik (93-179/711-795) and the Āthār of Abū Yūsuf (b. 113/731-732; d. 182/798).) This figure indicates that $N_{v}(1, Y)$ did not cease to slowly grow until 250 A.H., and that $N_{v}(2, Y)$ constantly increased, the pace at which it grew being higher from 190 onwards than before. It follows, phenomenally, that traditionists continued to reformulate hadiths at least during the period from 150 to 250.

Verifying whether this was actually the case is beyond the reach of this essay. Suffice it here to refer to two points. First, there are cases in which the earliest work that records a hadit th belonging to a particular variant was composed much later than the period in which the legal opinion underlying that variant was put forward. For example, according to a hadith recorded in the Sunan of Ibn Mājah (d. 273/886), the Prophet stated, "The right of pre-emption is like loosening the knot (that restraints the camel)." ${ }^{5}$ A longer variant of this hadīth recorded in the Kämil

$5 \quad$ Abū 'Abd Allāh Muḥammad ibn Yazīd b. Mājah al-Qazwīnī, Sunan al-Hāfiz Ab̄̄ 'Abd Allāh Muhammad ibn Yazìd al-Qazwīnī ibn Mājah, ed. Muḥammad Fu'ād 'Abd al-Bāqī, 2 vols. (Beirut: Dār al-Fikr, n.d.), 2:835, no. 2500. 
$f_{\grave{\imath}} d u$ 'afä' al-rijāl of Ibn 'Adī (d. 365/975-976) reads that the Prophet said, "The right of pre-emption is established neither for an absentee nor for a minor nor if a co-owner exercises it before another co-owner. The right of pre-emption is akin to loosening the knot (that restraints the camel)." ${ }^{\prime 6}$ The two hadiths are inspired by the idea that it is necessary to restrain the exercise of pre-emption right, for it can be harmful to the buyer. This idea is attributed to Ibrāhīm al-Nakha' $\overline{1}$ (Kufa, d. 97/715-716) and 'Uthmān b. Sulaymān al-Battī (Basra, d. 143/760-761), but Ibn Mājah's Sunan is the first writing that records a hadīth inspired by this idea. Generally speaking, growth in the number of variants does not necessarily mean a corresponding legal development.

Secondly, the rapid growth in $N_{v}(2, Y)$ is due primarily to a combination or an extraction of existing matns. For example, hadith no. 14294 recorded in Ibn Hanbal's Musnad reads that the Prophet forbade muhāqala, muzāabana, mukhābara, mu'āwama, and thunyā. ${ }^{7}$ Ibn 'Ulayya (d. 193/808-9) is the first transmitter who related a variant that refers to the prohibition of all of these five transactions to an author (Ibn Hanbal in this case) who recorded this variant, while variants referring to two to four among these transactions are related by earlier transmitters. Apparently, this hadīth is a composite hadīth in which existing hadīths were combined and was not generated by a change in legal doctrine. Conversely, Ibn Māja received hadīth no. 2455 (isnād: Muḥammad b. Yahyā $\leftarrow$ Muțar-

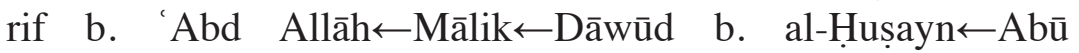
Sufyān), which reads that Abū Sa '̄id al-Khudrī narrated, "The Messenger of God forbade muhāqala. Muhāqala is a lease of land." This matn seems to have been extracted from a hadīth re-

6 Abū Aḥmad 'Abd Allāh b. 'Adī al-Jurjānī, al-Kāmil fì ḍu 'afă' al-rijāal, ed. Lajnat al-Mukhtașșin bi-Ishrād al-Nāshir, 7 vols. (Beirut: Dār al-Fikr, n.d.), 6:180, cf. Abū Bakr Aḥmad ibn al-Husayn ibn 'Alī al-Bayhaqī, al-Sunan al-kubrāa, 10 vols. (Beirut: Dār al-fikr, n.d.), 6:108, nos. 11368-369.

7 Aḥmad b. Muḥammad b. Hanbal, al-Musnad, ed. Aḥmad b. Muhammad Shākir, 20 vols. (Cairo: Dār al-Ḥadīth, 1416/1995), 11:425, no. 14294.

8 Ibn Mājah, Sunan, 3:517, no. 2455. Mukhābara is a kind of sharecropping contract. This name is often said to have derived from Khaybar, where a share cropping contract was concluded between the Prophet and the Jews who 
corded in Mālik's Muwațta'(isnād: MālikŁDāwūd b. al-

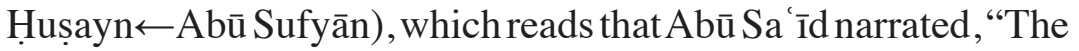
Messenger of God forbade muzābana and muhāqala. Muz̄̄bana is selling ripe dates for dried dates while they were still on the trees. Muhāqala is lease of land in exchange for wheat." Apparently, many variants referring to one or more of these prohibited transactions were generated by combining or extracting from existing hadīths. This is why $N_{v}(2, Y)$ grew rapidly.

Therefore, it is premature to draw some definite conclusion from this figure. It should be complemented by a close examination of individual hadīths. It is not rare that an unexpected outcome is obtained from a quantitative analysis, as noted. I did not expect that the pace at which the number of variants of hadiths belonging to Group 2 would increase during the period from 200 to 260 , i.e., the lifetime of the authors of the six canonical hadīth collections, as shown by Figure 1. I expected that the pace would have slowed down, for the authors compiled hadith collections because they believed that the matns they received from their teachers were definite and should not be reformulated, that is to say, they compiled hadīth collections to fix the matns. The quantitative approach is revealing in this sense, but the meaning of its outcome is not always immediately evident.

\footnotetext{
inhabited there. Ibn 'Abd al-Barr, Tamhīd, 2:321; cf. William J. Donaldson, Sharecropping in the Yemen (Leiden, Boston, Köln: Brill, 2000), 36; Shihāb al-Dīn Abū al-Faụl Aḥmad b. Hajar al-'Asqalānī, Fath al-bārī sharh Ṣah̄ịh al-Bukhārī, eds. 'Abd al-'Azīz ibn 'Abd Allāh ibn Bāz and Muḥammad Fu'ād 'Abd al-Bāqī, 13 vols. (Beirut: Dār al-Ma rifa, n.d.), 5:14. Mu'āwama denotes a sale of date palms for several years, i.e., for limited years. Muslim b. al-Ḥajjāj al-Qushayrī al-Naysābūrī, Șahīh Muslim, ed. Muḥammad Fu' ād 'Abd al-Bāqī, 5 vols. (Beirut: Dār Iḥyā' al-Turāth al-'Arabī, n.d.), 3:1175, no. 1536 (85). Thunyā in this hadīth seems to refer to a sale with a clause conferring on the seller the right to repurchase the object. Cf. Abu alWalīd Muḥammad b. Aḥmad b. Rushd al-Jadd, al-Muqaddamāt al-mumahhadāt, eds. Muḥammad Ḥajjī and Sa '̄ôd Aḥmad A rāb, 3 vols. (Beirut: Dār al-Gharb al-Islāmī, 1408/1988), 2:64-65

9 Mālik b. Anas, al-Muwațta', recension of Yahyā b. Yahyā al-Laythī, 2:149, no. 1828 .
} 
Roundtable on Islamic Legal History \& Historiography

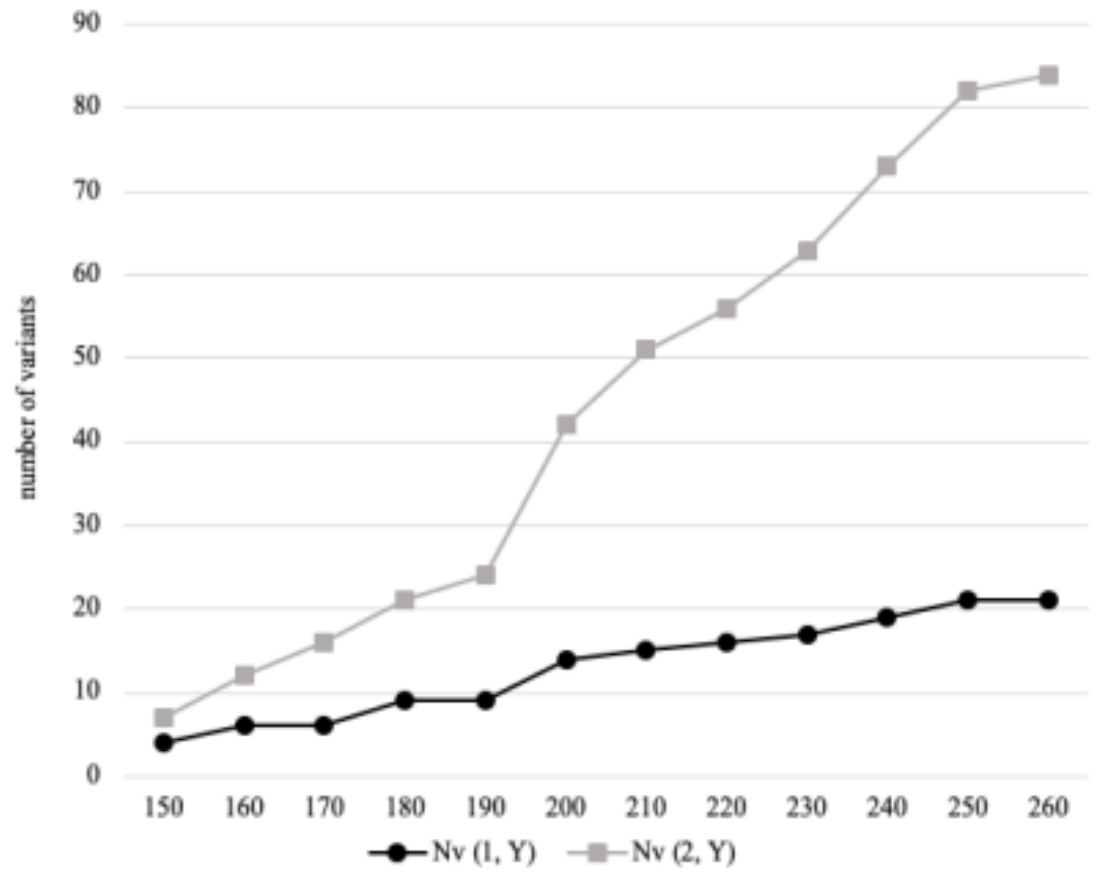

Figure 1. CHANGES IN THE NUMBer OF VARIANTS OVER TIME 